\title{
Competititve strategy of taxi company in facing environmental changes
}

\author{
Ahmad Saifi Athoillah" ${ }^{*}$, Muhammad Firdaus², and Bunasor Sanim ${ }^{3}$ \\ ${ }^{1}$ Management and Business, School of Business, IPB University \\ Jalan Raya Pajajaran, Bogor 16128, Indonesia \\ ahmadsaifiathoillah@outlook.com \\ ${ }^{2}$ Department of Economics, Faculty of Economics and Management, \\ IPB University \\ Jalan Agatis Kampus IPB Darmaga, Bogor 16680, Indonesia \\ firdausfemipb@yahoo.com \\ ${ }^{\mathbf{3}}$ Department of Economics, Faculty of Economics and Management, \\ IPB University \\ Jalan Agatis Kampus IPB Darmaga, Bogor 16680, Indonesia \\ bunasorsanim441@gmail.com
}

\begin{abstract}
This study aims to analyze the satisfaction of taxi passengers, the internal and external factors in PT XYZ and formulate the competitive strategy with conventional taxi competitors and online taxi companies. The scope of this research is specifically focused on the competitive strategy in the strategic business unit level. This study uses a quantitative descriptive approach. The data analysis techniques used are IFE, EFE, IE, and QSPM. The result of this study on the analysis of EFE, PT XYZ shows that the highest strength is on a strategic distribution network of the taxi in big cities. Meanwhile, the highest threats are standardization of tariff, the number of the taxi, and the minimum identity of the online taxi. Furthermore, IE matrix analysis shows that PT XYZ is in quadrant I (grow and build strategy). The decision-making stage based on the QSPM matrix has the order of strategic priority as follows: forward integration, backward integration, horizontal integration, product development, market penetration, and market development.
\end{abstract}

Keywords: competitive strategy; EFE; IFE; IPA; QSPM.

Received: July 3, 2019; Accepted: August 21, 2019; Published: October 18, 2019

*Corresponding author

Email: ahmadsaifiathoillah@outlook.com

How to cite this document:

Athoillah, A. S., Firdaus, M., \& Sanim, B. (2019). Competitive strategy of taxi company in facing environment changes. BISMA (Bisnis dan Manajemen), 12(October), 66-87. https://doi.org/10.26740/bisma.v12n1.p66-87 


\begin{abstract}
Abstrak
Penelitian ini bertujuan untuk menganalisis kepuasan penumpang taksi, menganalisis faktor internal dan eksternal pada PT XYZ dan merumuskan strategi kompetitif dengan pesaing taksi konvensional dan perusahaan taksi online. Ruang lingkup penelitian ini secara khusus difokuskan pada strategi kompetitif di tingkat unit bisnis strategis. Penelitian ini menggunakan pendekatan deskriptif kuantitatif. Teknik analisis data yang digunakan adalah IFE, EFE, IE, dan QSPM. Hasil penelitian ini pada analisis EFE, PT XYZ menunjukkan bahwa strength tertinggi adalah pada jaringan distribusi taksi yang strategis dan kuat di kota-kota besar. Sementara itu, ancaman tertinggi adalah standardisasi tarif, jumlah taksi, dan identitas minimum taksi online. Selanjutnya, analisis matriks IE menunjukkan bahwa PT XYZ berada di kuadran I (strategi tumbuh dan bangun). Tahap pengambilan keputusan dengan matriks QSPM memiliki urutan prioritas strategis sebagai berikut: integrasi ke depan, integrasi ke belakang, integrasi horizontal, pengembangan produk, penetrasi pasar, dan pengembangan pasar.
\end{abstract}

Kata kunci: EFE; IFE; IPA; QSPM; strategi kompetitif.

\title{
INTRODUCTION
}

Technology and information are unseparated aspects of everyday life in this digital era. For the business world, the role of technology and information is prominent in determining whether to run or not run the business. Not surprisingly, many companies are competing to update themselves in providing quality services on products or services. This indirectly raises high competition, both in the internal and external environment of the company. Riady (1999) reinforces this paradigm which states that one of the triggering factors of competition in the business environment is the presence of technology and information.

One of the consequences if the company is insensitive to technology is the company's inability to control its resources. As a result, strategic decision making will be disrupted and put the company in a bankrupt position. In Indonesia, one of the industries that experiences fierce competition is taxis.

The development of the taxi industry in a decade has generally experienced a significant development, since the entry of application-based or online taxis to Indonesia in 2014. Indirectly, this has led to major environmental changes, the easy way and style of society. Using a smartphone, people can order taxis provided by application-based or online taxi companies, such as Go Car, Uber Car, and Grab Car. Uber Taxi is an online taxi that firstly entered to Indonesia and immediately received positive response from consumers. However, the supply of rental vehicles has increased radically with the entry of Uber in 2011. Using a mobile application, Uber allows customers to travel which then sent to the nearest Uber driver. These drivers use their own cars and the costs vary depending on the level of demand relative to the level of supply. Uber prices are generally cheaper than traditional taxis (Sullivan, 2015). 
Indirectly, the presence of this online taxi, creates a digital economic environment that leads to mobile transportation with internet and applicationbased. With this trend, the conventional big taxi companies that first succeeded were PT XYZ, PT Kosti Jaya, PT Gamya, PT Koperasi Taksi Indonesia, PT Citra Transpor Nusantara, PT President Taksi, PT Dian Taksi, PT Sri Medali (DKI Transportation Agency) (2013) are required to set appropriate and sustainable strategies. Furthermore, the phenomenon of the presence of online taxis is a threat to conventional taxi companies that have become global in nature. This means that this phenomenon is also faced by taxi companies around the world such as Yellow Taxicabs in the United States, Black Cab in the United Kingdom, Hinomaru in Japan, and Premier taxis in Singapore (Wymant, 2013).

One of the conventional taxi companies that experienced a big impact due to the entry of online taxis is PT XYZ. PT XYZ is one of the largest conventional taxi operator companies in Indonesia. The company, which is headquartered in Jakarta, is a corporate taxi business group consisting of 3 business units: regular taxis, premium taxis, and value added transportation businesses such as bus, car and motorbike rental. In 2014, PT XYZ's market share was $30 \%$ of the national taxi market. Meanwhile, the number of passengers of PT XYZ by $97 \%$ is in Jadetabek and 3\% outside Jadetabek (Annual Report of PT XYZ, 2015). The number of market shares and the number of passengers has continued to decline, since the entry of online taxis at the end of 2014 and early 2015.

In the span of 2014 and 2015, there were three new application-based/online taxi companies that entered Indonesia, namely PT Uber Indonesia Technology, PT Grabbike Indonesia, and PT Gojek Indonesia. Although the three companies have just entered Indonesia, it is estimated that online taxis will continue to grow by $7 \%$ the following years (Credit Suisse Estimates, 2015). The rapid growth of online taxis, this has an impact on the conventional taxi operating system which is quite complicated. This was also indirectly faced by PT XYZ.

There are three main problems faced by PT XYZ since the advent of online taxis, namely: (1) Declined financial performance; (2) Decreased taxi operating productivity; (3) Unequal competition among fellow taxi fare. All three problems are interrelated, thus creating a vicious cycle that is difficult to resolved.

First, the decline in financial performance caused by a decrease in driver revenue, as shown in Apendix 1. Apendix 1 shows the value of PT XYZ's revenue tends to decrease. An interesting thing to observed is that the revenue level in 2016 began to decline by $36.27 \%$ or to Rp 618.2 billion compared to 2015 which was Rp 970.1 billion. This decline continued until 2017 that the revenue level fell sharply by $62.54 \%$ to Rp 231.6 billion compared to 2016 which amounted to $\mathrm{Rp}$ 618.2 billion.

Secondly, decreased driver's productivity and taxi operations. The presence of online taxis has an impact on low levels of deposit productivity. This resulted in a 40\% decrease in deposits per day (Financial Report of PT XYZ, 2016). This 
situation made PT XYZ a decrease in the number of taxis in the 2009-2017 period, as observed in Apendix 2. Appendix 2 shows the number of regular taxis in 2009-2017 has declined. In 2015, regular taxis did not increase in the number of taxis from 2014 to 2016, which was fixed at 11,050 taxis. However, in 2017 the number of taxis decreased by 1,350 taxis to 9,700 taxis as of September 2017.

Third, the high tariff competition and decreased market share. The high level of tariff competition makes PT XYZ becomes less competitive in terms of taxi fares, so drivers do not reach the deposit (revenue) standard given by the company. PT XYZ taxi fares are rated higher than online taxis, as shown in Apendix 3. Apendix 3 shows that online taxis have competitive tariff power compared to conventional taxis, which are on average $30 \%$ cheaper per kilometer. This is because online taxis use taxi fares that below the standards set by the government. Indirectly, cheap online taxi fares results in the shift of conventional taxi passengers to online taxis. One impact is the low level of work productivity where the driver does not reach the company's deposit target.

Considering further at the three problems of PT XYZ, it is very important PT XYZ to conduct a competitive strategy appropriately (Priyadi 1998). This is inseparable from the great potential in the taxi industry in Indonesia.

Furthermore, considering Indonesia's large population with a projected growth of 28.6\% in 2035 (BPS 2016). According to the Association of Indonesian Internet Service Providers / APJII (2016) states that internet users in Indonesia amounted to $51.8 \%$ or 133.64 million people, of which 92.8 million people used the internet for travel purposes and 34.1 million were used for shopping for travel tickets.

With a viral and vital phenomenon in taxi competition, the title of this study is "Competing Strategies for Taxi Companies in Facing Environmental Change". The purpose of this study is to analyze the internal and external environmental factors that influence PT XYZ and to formulate PT XYZ's competitive strategy to achieve competitive advantage in dealing with taxi companies.

\section{Strategic Management}

Strategy can be defined in two ways: "as a pattern that emerges in a sequence of decisions over time, or as an organizational plan of action that is intended to move a company toward achievement of its shorter-term goals and ultimately its fundamental purposes" (Enz, 2010). Strategic management is the process of evaluating decisions taken from managerial actions to determine the company's performance in the long run (Dess et al. 2003). According to Wit and Mayer (2003) states that in strategic management there are 4 levels of strategy, namely: (1) Network level strategy, which is a strategy that aims to globalize the business by building networking between one company and another company; (2) Corporate-level strategy, which is a strategy that describes the overall direction of 
the company towards the management of various business units; (3) Business level strategy is a strategy that is applied at the division or business unit level of the company; (4) Functional level strategy, this strategy is used at the functional level, such as marketing; finance; and human resources.

The field of strategic management deals with: (1) The major intended and emergent initiatives (2) Taken by general managers on behalf of owners; (3) Involving utilization of resources; (4) To enhance the performance; (5) Of firms (6) In their external environment (Nag et al., 2007, p. 942).

The study by Hasian (2014) conducted a strategic management research company taxi company PT Express Transindo Utama Tbk at the level of corporate strategy. The purpose of this study is to analyze corporate corporate strategy with fellow conventional taxis. The method used is play to win analysis, Porter Five Forces and VRIO. The results showed the most appropriate strategy was the best cost provider strategy and differentiation strategy. This strategy focuses on applying cheap taxi fares (lower limit tariffs) set by the government.

\section{Competitive Advantage}

The company decisions about organizational design and the company's competitive strategy are very important to gain competitive advantage and to improve company performance. Researchers have studied the relationship between strategy, and structure, for a long time, based on contingency theory (Chandler, 1962; Ortega, Azorin and Cortes, 2010). This approach states that optimal organizational design depends on strategy, including several factors that influence it. A competitive strategy is developing a plan for how the business will compete, what the goal should be and what policies are needed to achieve that goal (Porter 2001). According to Porter, the competition map in the market involves Porter Five Forces. The five factors of porter competition are (1) Threats from new entrants; (2) Barriers to entry; (3) Bargaining power; (4) Buyer's strength; (5) Threats from substitute products.

The research about competitive strategy in the taxi industry was conducted by Subagja (2016) with Porter Five Forces, SWOT, BCG, and QSPM methods. The purpose of this study is to analyze the competitive strategy of the taxi business in Indonesia. The object of research is PT Blue Bird Tbk. The results of the research on alternative strategies adopted by the company are: (1) The addition of a taxi fleet; (2) Increase coverage at new locations especially at the municipal level; (3) Improve service quality and operating efficiency; (4) Increasing the limousine business division in several cities; (5) Increase company profitability.

Similar research was also carried out by Chaudhary and Joshi (2016) using Porter Five Forces model and SWOT. SWOT has been used in various fields of current and emerging issues (Syazwan Ab Talib and Bakar Abdul Hamid, 2014; He and Liao, 2012; Helms et al., 2011; Panagiotou, 2003; Glaister and Falshaw, 
1999). Fertel et al. (2013) used SWOT analysis on the themes of energy security, energy efficiency, technology and innovation. The results showed that there were two strategies. The first strategy is creating different services and other transportation. Furthermore, the private vehicle tax was not allocated for public infrastructure development. The similarity of this previous research with this study is the research object. Moreover, SWOT has been used by many practitioners, marketing researchers, and becomes a frequent and popular tool in marketing and business strategy. Its simplicity and interesting acronym have often been used in business as a way to find alternatives to make decisions in a complex and dynamic environment. In the business arena, grouped internal and external problems are a frequent starting point for strategic planning (Ortega, Azorin and Cortes, 2010).

The research on competitive strategies observed multi taxi companies was conducted by Zhao and Xing (2012) using the Importance Performance Analysis (IPA) method. The purpose of this study is comparing the conventional taxi company reservations with online taxis in China. The results of the study stated that IPA quadrant on the online taxi company which has a higher level of performance than conventional taxis to be in quadrant II. This means that passengers are more interested in ordering a taxi with a smart phone rather than conventional taxi bookings and all the advantages of online taxis in terms of reliability, responsiveness, assurance, empathy and tangibles. The research of Zhao and Xing above was supported by He and Shen (2015) with the research method used is Spatial Equilibrium, a model that describes the balance of the process of spatial interaction of the values of the research variables for several regions together. The number of samples is 300 taxis $(\mathrm{N}=300)$, from the number of $\mathrm{N}$ divided into 2 models, namely: (1) Taxi companies use the application; (2) The company does not use the application / conventional. The results of the study that the best proposed model is that taxi passengers are better off ordering taxis online. The difference with the research conducted by the author is on the subject, object, method and scope of the discussion. The subject of research uses a competitive strategy of regular taxi company types. The object of research is PT XYZ. Meanwhile, the analytical methods used are Porter Five Forces Model, Internal Factor Evaluation (IFE), External Factor Evaluation (EFE), InternalExternal (IE), Quantitative Strategic Planning Matrix (QSPM). The scope of discussion focuses on competitive strategies at the business unit level. The flow of thought concepts in this study can be seen in Figure 1.

\section{METHODS}

This research is categorized into a case study with a quantitative descriptive approach which emphasized on the aspects of systematic, planned and objective 
structured measurement of an organization, institution and certain symptoms that become social phenomena in the community (Sugiyono 2012).

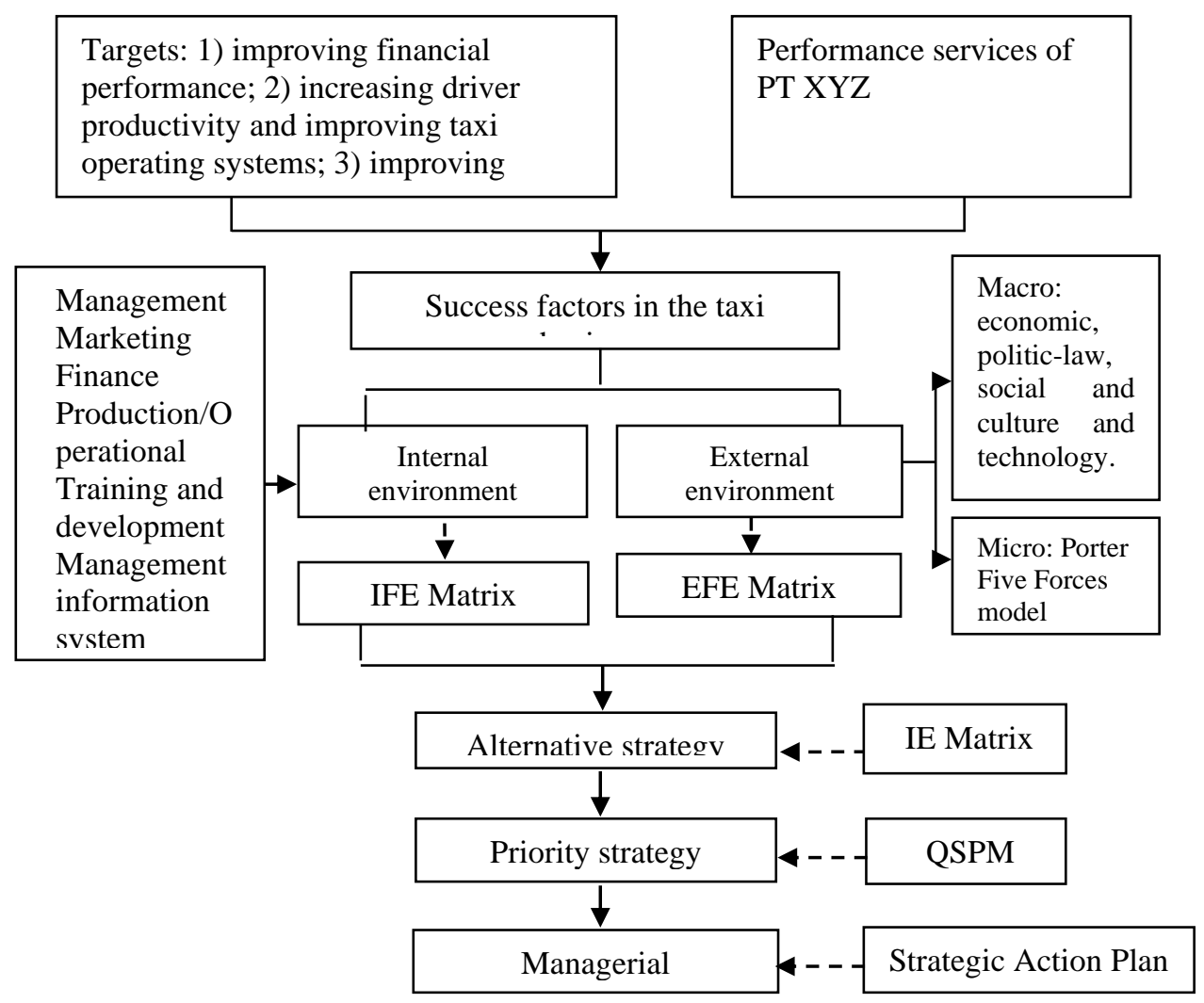

Figure 1. Research Framework

Types and sources of data in this study are primary data and secondary data. The primary data obtained from questionnaire surveys to expert respondents. The expert respondents consisted of two parties, namely internal and external parties. The internal party of the management of PT XYZ has the authority in making decisions for the company. Meanwhile, the external party is the DKI Jakarta Transportation and Transportation Office which consists of two expert respondents. The secondary data are from literatures such as journals, books, scientific articles, and other credible supporting data. The research data collection technique was carried out by questionnaire survey, observation, interview and literature study.

The data collection techniques through questionnaire surveys to expert respondents was done to determine the company's internal and external conditions. The expert respondents consisted of two parties, namely internal parties to the management of PT XYZ who had the authority in determining strategic decisions in the direction of the company and had an understanding of the research topic, namely the corporate strategy of PT XYZ. Internal party expert respondents consisted of 5 expert respondents namely Head of Human Capital, People Development Manager, Industrial and Reclation Manager, General Affairs 
Manager, and Staff Recruitment Company. Meanwhile, the expert respondent from the external party is the government as the vehicle transport regulator, namely the Jakarta Transportation and Transportation Department. The external respondents consist of two expert respondents, namely the Head of DKI Jakarta Transportation Agency's Insider Road Transportation Section, and the DKI Jakarta Transportation Agency's Transportation Insider Road Staff.

Research data analysis techniques are using five methods of analysis, namely: Porter Five Forces, Internal Factor Evaluation (IFE) Matrix, Matrix of External Factor Evaluation (EFE), Internal-External Matrix (IE), and Quantitative strategic planning (QSPM).

\section{Porter Five Forces}

It is a method to analyze the attractiveness of an industry in the long run. The industry attractiveness consists of strengths, the threat of newcomers, barriers to entry, the strength of suppliers, the strength of buyers and the threat of substitute products (Porter 2008). The questionnaire score of this study uses 1-4 grades, which are (1) Low; (2) Moderate; (3) High; (4) Very high. The score assessment was obtained from the seven expert respondents taken purposively to the management of PT XYZ and the DKI Jakarta Transportation and Transportation Department.

\section{Internal Factor Evaluation (IFE) Matrix}

It is a method in strategic management to evaluate strengths and weaknesses (Zulkarnain et al. 2018). The IFE matrix is carried out in five steps, namely: (1) Identification of internal key factors such as internal audits to identify company's the strengths and weaknesses. In this study, there were 20 internal strategic factors that were identified based on the results of research observations; (2) Giving weights. The weight given ranges from 0.00 to 1.00 for each factor entered. After assigning weights to each factor it is necessary to ensure that the sum of all weights must be equal to 1.00; (3) Scale up including setting a rating scale for each factor. Researchers use a rating scale of 1-4. With criteria for 1 is not good, 2 is not good, 3 good, 4 is very good; (4) Weight and scale calculation; (5) Add the weights to the rating scale including summing the weighted scores for each factor that considered as the final score.

\section{Matrix of External Factor Evaluation (EFE)}

The EFE matrix is a method for assessing a company's response to its external conditions (Zulkarnain et al. 2018). The steps for evaluating the EFE matrix are as follows: (1) Make a critical success factor list of both opportunities and threats. In this study there are 20 external strategic factors of the company based on the study of research observations; (2) Determine the weight of the critical success factor. Total weight must be 1.0; (3) Determine the rating of each 
critical success factor between 1-4 which includes: $1=$ elow average, $2=$ average, 3 = above average, 4 = very good; (4) Rating is determined based on the effectiveness of the company's strategic priorities; (5) Multiply the weight value by the rating value to get the critical success factor score; (6) Add up all the scores to get the total score for the assessed.

\section{Internal-External Matrix (IE)}

The IE matrix is based on an analysis of internal and external environmental factors which are combined into one suggestive model as shown in Figure 2.

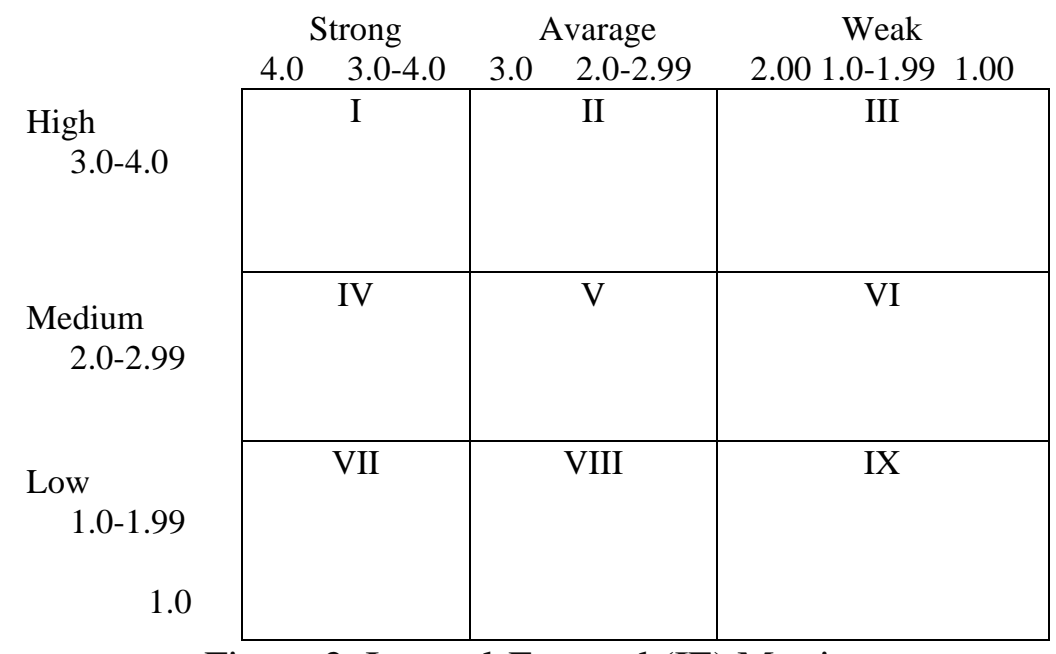

Figure 2. Internal-External (IE) Matrix

In Figure 2, it can be observed that if being visualized, the company must hold and maintain its position. There are nine cell strategies and briefly grouped into three main strategies (Kuncoro 2005), namely: (1) Growth strategy is the company's own growth strategy (cells 1,2 and 5) or product diversification efforts (cells 7 and 8); (2) Stability strategy is a strategy that implemented without changing the direction of the strategy; (3) Retrenchment strategy (cells 3, 6, and 9) is a strategy to reduce the effort made by the company.

\section{Quantitative Strategic Planning (QSPM)}

QSPM is an analytical method for objectively evaluating alternative strategies based on internal and external success factors identified earlier (David 2011). The total number of internal and internal strategic factors is 40 factors. The data processing technique uses four stages of research, namely: (1) Observation of the company's internal environment is done by observing the internal state of PT XYZ and government agencies; (2) Questionnaire survey to expert respondents. At this stage, researchers determine the weight and rating on the IFE and EFE matrices. This stage aims to answer the purpose of the first research that analyze the internal and external factors that affect PT XYZ; (3) Internal-external (IE) matrix analysis. The output produces an alternative strategy recommended by the company; (4) QSPM matrix analysis whose output generates a priority strategy 
sequence. The output of this analysis aims to answer the second research objective, which is to formulate PT XYZ's competitive strategy.

\section{RESULT AND DISCUSSION}

\section{The Analysis of Internal Environment of Company}

To analyze and identify internal and external factors, organizations use the SWOT matrix. By determination of these factors, the developed strategies may be built on the strengths or eliminate the weaknesses, exploit the opportunities or counter the threats (Wang et al., 2014; Zhang and Feng, 2013; Dyson, 2004).

\section{The Evaluation of Internal Factor Evaluation Matrix (IFE)}

Table 1. The Result of IFE Analysis Matrix in PT XYZ

\begin{tabular}{lccc}
\hline \multicolumn{1}{c}{ Internal Factors } & Weight & Rating & Score \\
\hline Strength & & & \\
The large amount of fleet and taxi poll & 0.0476 & 3.2 & 0.1524 \\
The strong taxi distribution network in big cities & 0.0547 & 4.0 & 0.2187 \\
A highly-performed service quality & 0.0488 & 3.6 & 0.1755 \\
The floor-rate of taxi in PT XYZ & 0.0502 & 4.0 & 0.2008 \\
A high loyalty of driver and passengers & 0.0478 & 3.2 & 0.1530 \\
Frequent numbers of passengers. & 0.0449 & 3.0 & 0.1348 \\
Operation and product maintenance (taxi allocation, spare parts & 0.0557 & 2.6 & 0.1449 \\
equipments and tools & & & \\
An efficiency of company's operational cost. & 0.0562 & 3.8 & 0.2134 \\
The strategic location of office and taxi poll & 0.0557 & 3.8 & 0.2116 \\
The company has diversity (VATB) and premium taxi type. & 0.0603 & 3.6 & 0.2172 \\
The ability to make a partnership with government and non- & 0.0468 & 3.6 & 0.1683 \\
government & & & \\
The well-running and profitable system of driver partnership & 0.0482 & 2.6 & 0.1254 \\
with company & & & \\
A good incentives/compensation to employees & 0.0535 & 3.2 & 0.1713 \\
Weaknesses & & & \\
The revitalization of taxi fleet needs high cost. & 0.0531 & 2.8 & 0.1486 \\
Weak financial performance/position & 0.0498 & 4.0 & 0.1991 \\
High cost technology infrastructure revitalization & 0.0459 & 4.0 & 0.1837 \\
Less research, development and innovation & 0.0478 & 2.0 & 0.0955 \\
Decreased driver's revenue/deposits & 0.0451 & 3.6 & 0.1623 \\
minimum quality of human resource in technology. & 0.0473 & 3.0 & 0.1420 \\
Passive marketing and tariff promotion. & 0.0407 & 3.8 & 0.1547 \\
\hline \multicolumn{1}{c}{ Total } & 1 & 3.3733 \\
\hline Source: Result of the research (2019) & &
\end{tabular}

Source: Result of the research (2019)

IFE matrix analysis is the result of the identification of internal environmental factors in the form of strengths and weaknesses owned by PT $X Y Z$. The validation mechanism for the IFE matrix score assessment is based on the results of the questionnaire survey data processing for five senior managers of PT XYZ who have credibility in making strategic corporate decisions namely Head of Human Capital, People Development Manager, Industrial and Relation Manager, General Affair Manager, and Company's Staff Recruitment. The 
technical assessment of scores is carried out by researchers based on the steps in the discussion of research methods. In Table 1, it can be observed that the calculation using the IFE matrix shows that the total score of PT XYZ is 3.3733.

Table 1 shows that the results of calculations using the IFE matrix obtained a total score owned by PT XYZ of 3.3733. With a total weighting score above 2.5, it indicates that the company's internal position is quite capable of overcoming existing weaknesses with its strengths. Furthermore, the results of the IFE matrix show that influential for PT XYZ is a strong and strategic taxi distribution network in big cities (score 0.2187). Meanwhile, the main weakness of PT XYZ is the financial position that not strong (score 0.1991).

\section{Corporate External Environment Analysis}

Table 2. Recapitulation of Questionnaire Analysis of Porter Five Forces

\begin{tabular}{|c|c|c|}
\hline Industry areas & Score & Notes \\
\hline \multicolumn{3}{|l|}{ Threats of new entry } \\
\hline Economic of scale & 2.50 & High \\
\hline The barrier's differentiation & 2.75 & High \\
\hline Capital needs & 4.00 & Very high \\
\hline Access to distribution network & 3.75 & Very high \\
\hline The product quality of barrier & 3.00 & Very high \\
\hline Government regulation & 4.00 & Very high \\
\hline Predicted rejected actions & 2.25 & Medium \\
\hline The price of barrier & 3.75 & Very high \\
\hline Technology of barrier & 3.75 & Very high \\
\hline Experience as the barrier & 2.25 & Medium \\
\hline \multicolumn{3}{|l|}{ Bargaining power of supplier } \\
\hline The supplier group & 3.50 & Very high \\
\hline The substitution product & 2.75 & High \\
\hline Important customer & 4.00 & Very high \\
\hline Government & 4.00 & Very high \\
\hline \multicolumn{3}{|l|}{ Bargaining power of customer } \\
\hline Customer/passenger group & 3.75 & Very high \\
\hline Product differentiation & 4.00 & Very high \\
\hline Threats of customer integration & 3.50 & Very high \\
\hline Product quality & 3.25 & High \\
\hline Taxi rate/fare & 4.00 & Very high \\
\hline \multicolumn{3}{|l|}{ Threats of Product Substitution } \\
\hline Public transportation & 4.00 & Very high \\
\hline Private vehicle & 3.75 & Very high \\
\hline Taxibike & 3.75 & Very high \\
\hline \multicolumn{3}{|l|}{ Competitive rivalry } \\
\hline Competitor numbers & 3.00 & High \\
\hline Industry growth level & 3.00 & High \\
\hline High fixed cost & 4.00 & Very high \\
\hline
\end{tabular}

Source: Result of the research (2019)

The purpose of analyzing the micro external environment through the Porter Five Forces model is to analyze the level of competitive competition of taxis at the industrial level. The results of this study can help companies to analyze the level of competition in taxi competition from the parameters of the 
threat of new entrants, bargaining power of suppliers, bargaining power of buyers, threat of substitute products, and competitive rivalry. The assessment of the score was obtained from four expert respondents who were taken purposively, namely 2 senior management of PT XYZ (Head of Human Capital, Industrial and Relation Manager and 2 from DKI Jakarta Transportation Agency (Head of DKI Jakarta Transportation Agency's Insider Road Transportation Section and Staff) Sector of Transportation in the Roads of DKI Jakarta Transportation Agency Route) as presented in Table 2.

In Table 2, it can be observed that the threat of new entry, PT XYZ faced in online taxi competition was capital requirements and government regulations, with a score of 4.00 each. The analysis in Table 2 shows that to win the competition of the taxi industry, PT XYZ must pay attention to these two strengths.

In the bargaining power of suppliers, the highest attractiveness are customers and the government, with a score of 4.00 each. In the buyer's bargaining power, the highest strength is product differentiation and price, each at 4.00. The threat of substitute products in the taxi industry is public transportation (score 4.00). Moreover, the competitive rivalry in industry determined by fixed taxi costs (score 4.00).

\section{External Factor Evaluation (EFE) Matrix Analysis}

EFE matrix analysis is the result of identifying external factors in the form of opportunities and threats that affect the taxi industry, especially to PT XYZ. Rating is based on the results of a questionnaire survey of seven expert respondents both from the management of PT XYZ and the Jakarta Transportation Agency. The technical validation of weights and scores are done by researchers based on the results of the survey of expert respondents as presented in Table 3.

Table 3 obtained the total score of 3.3645. With a weighting score above 2.5 indicates that the company is able to respond effectively to external factors by utilizing existed opportunities to overcome threats. The main opportunity the company is a high level of mobility and transportation needs with a score of 0.2554. The main threat of PT XYZ is the standardization of tariffs, fleet numbers, and the identity of online taxi vehicles with a minimum score of 0.2135 .

\section{Internal-External Matrix Analysis (IE)}

Internal-External (IE) matrix analysis is performed to sharpen the analysis of the IFE and EFE matrices. Based on the mapping of the total score on the IFE matrix of 3.3733, it can be concluded that PT XYZ has a high level of internal factors. From this condition, it means that PT XYZ is able to manage the strengths and weaknesses contained in the taxi industry. While the total score on the EFE matrix is 3.3645, it can be concluded that PT XYZ has a high level of response or 
response to its external environment. This means that the company can manage opportunities, and able to mitigate risks from threats in the taxi industry. The results of weighting the internal and external factor matrices which included in the IE matrix as shown in Figure 3.

Table 3. The Result of EFE Matrix Analysis of PT XYZ

\begin{tabular}{lccc}
\hline \multicolumn{1}{c}{ External factors } & Weight & Rating & Score \\
\hline $\begin{array}{l}\text { Opportunity } \\
\text { The government regulation in determine the conventional }\end{array}$ & 0.0565 & 3.1 & 0.1750 \\
taxi and online taxi regulation. & & & \\
The high level of mobility and transportation needs. & 0.0639 & 4.0 & 0.2554 \\
The strong bargaining power of supplier. & 0.0540 & 2.3 & 0.1243 \\
The increased population growth & 0.0498 & 3.6 & 0.1791 \\
High Indonesian economic growth & 0.0439 & 3.3 & 0.1450 \\
Competition in the middle-income market & 0.0399 & 3.3 & 0.1316 \\
The focus strategy in domestic market & 0.0396 & 3.1 & 0.1229 \\
The high speed of information technology & 0.0484 & 3.3 & 0.1596 \\
The high purchasing power of society & 0.0546 & 4.0 & 0.2184 \\
Increased the numbers of office and entertainment place. & 0.0586 & 3.9 & 0.2287 \\
The low taxi differentiation. & 0.0595 & 2.4 & 0.1427 \\
The support of funding to investor and stakeholder. & 0.0525 & 3.7 & 0.1944 \\
Threats & & & \\
Entry of online taxi. & 0.0509 & 3.4 & 0.1730 \\
Low-price taxi rate in society. & 0.0543 & 3.3 & 0.1791 \\
Threats for product differentiation of taxi & 0.0490 & 3.1 & 0.1520 \\
Tariff standardization, the number of fleet and minimum & 0.0534 & 4.0 & 0.2135 \\
online taxi identity & & & \\
High competition in taxi industry & 0.0431 & 3.4 & 0.1464 \\
Easy ownership permit for vehicle owner & 0.0416 & 3.9 & 0.1623 \\
Technology development of competitors. & 0.0442 & 3.9 & 0.1723 \\
Inflation and increased input price. & 0.0423 & 2.1 & 0.0887 \\
\hline \multicolumn{1}{c}{ Total } & 1 & & 3.3645 \\
\hline Source: Result of the resear & &
\end{tabular}

Source: Result of the research (2019)

In Figure 3, the position of PT XYZ is in cell I implies growth and build strategy. The following is the strategies can be implemented at the business unit level which emphasizes how the company advances its organization in the regular taxi business unit.

\section{Vertical Integration Strategy Going Forward}

This strategy include the recommended programs: (1) Optimizing revenue through a diversity of Value Added Transportation Business (VATB) products and premium taxis that are not yet optimal; (2) The efficiency of cash flow in terms of maintenance of production and operations; (3) Revitalize and renewal the taxi fleet; (4) Increasing cooperation with government/ non-government agencies and companies in other fields. 
Total weight (score) internal strategic factor $=3.3733$

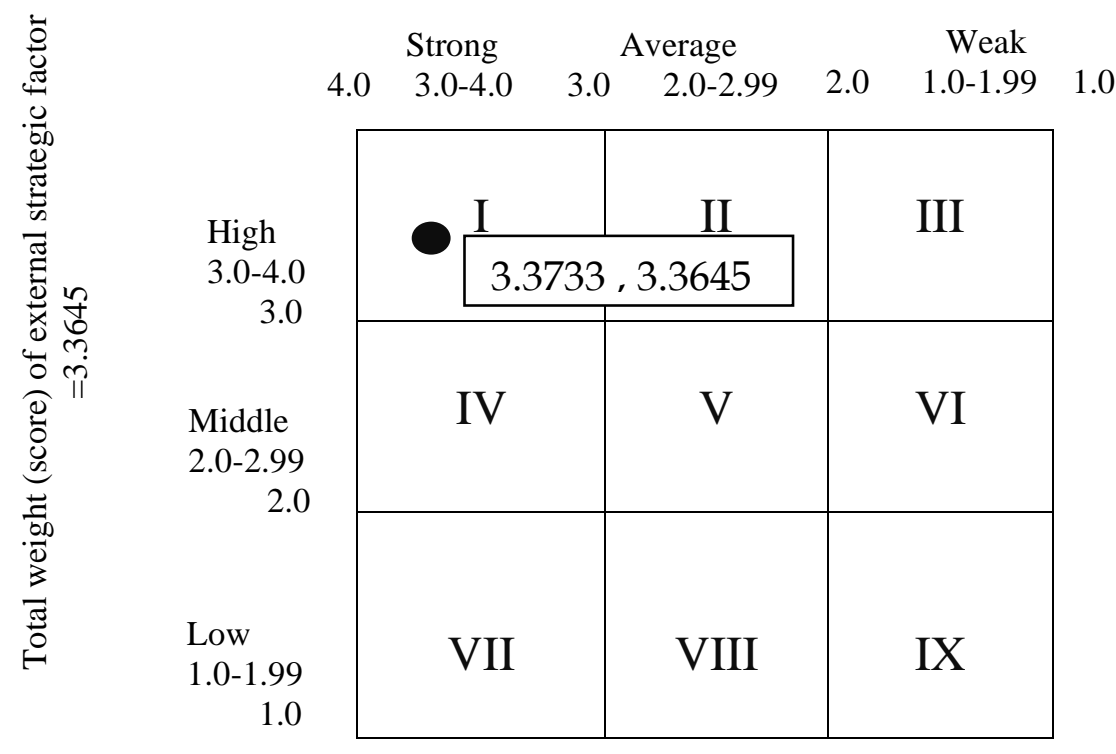

Figure 3. Total of Matrix Score IE PT XYZ

\section{Horizontal Integration Strategy}

This strategy include the recommended programs: (1) Increasing cooperation with vehicle suppliers (ATPM) and other component suppliers; (2) Add cooperation with other online taxi companies; (2) Improve the welfare of drivers through reviewing the partnership system and old age welfare; (3) Technology company cooperation in the effort to develop a taxi application owned by PT XYZ.

Product Development Strategy

This strategy include the recommended programs: (1) Develop taxi products with youth segments; (2) Conduct research on youth market segments and innovations in marketing; (3) Differentiate young people taxi with the right concepts: Strategy, Targeting, Positioning (STP); (4) Improve the quality of service and driver skills; (5) Opened office channeling in several strategic offices and entertainment venues; (6) Diversity of taxi products in the youth segment.

\section{Market Penetration Strategy}

This strategy include the recommended programs: (1) Increasing the area of taxi operational networks, namely the Jabodetabek area in the youth taxi segment; (2) Increase the number of taxi drivers; (3) Promoting the determination of differentiation of regular taxi products for young people in the Greater Jakarta area; (4) Maintain lower limit tariffs on regular taxis (low-cost tariffs) for middleclass consumers. 


\section{Market Development Strategy}

This strategy include the recommended programs: (1) Focusing on the domestic market; (2) Promoting intensively by giving discounts, promos, vouchers to the public/government agencies outside Jabodetabek in the youth taxi segment; (3) Recruiting employees in the field of Technology and Information (IT), Marketing, and Finance.

After obtaining several alternative programs as shown in Table 4, the attractiveness of the six alternative strategies to internal and external factors applied in the beginning of the strategy formulation. From the results of the attraction analysis, it can be summarized into the QSPM matrix in the competition of PT XYZ with online taxis.

\section{PT XYZ Priority Decision Making Strategic of PT XYZ}

The last step in the formulation of strategy is to make decisions with the QSPM matrix. At this stage of decision making a measurement of its relative appeal to internal and external factors is measured. Furthermore, each weight value on each internal and external factor will be multiplied by the value generated through the measurement of the attractiveness of each alternative strategy. The results of this multiplication show the total attractiveness of Sum Total Attributiveness Score (TAS) which becomes a priority strategy of PT XYZ. The following is a sequence of priority strategies: (1) Forward vertical integration strategy with a total TAS of 6.3715 ; (2) Backward vertical integration strategy with a total TAS of 6.3201 ; (3) Horizontal integration strategy with a total TAS of 6,1892; (4) Product development strategy with a total TAS of 5.9429; (5) Market penetration strategy with a total TAS of 5.9203; (6) Market development strategy with a total TAS of 5.7897.

\section{Managerial Implications}

Based on the analysis in the QSPM matrix, the sequence of strategies that become the company's priority is obtained. There are the managerial implications applied by PT XYZ:

\section{Forward Integration Strategy}

There are four forward integration strategies. (1) Optimize revenue through product diversity from other VATB business unit lines, including bus rental, motorbike rental, and premium cars and taxis; (2) Efficiency of cash flow in terms of maintenance in terms of production and operations (procurement of taxis, equipment spare parts, and fuel). Furthermore, the strategic step is to replace fuel with gas fuel or biogas (eco taxi) regularly; (3) Revitalize and rejuvenate the taxi fleet. This is very important because competitors have an average operating age of vehicles about less than five years (especially online taxi vehicles); (4) Increase cooperation with government agencies and companies in other fields, namely 
cooperation with e-commerce companies and financial technology (fintech) such as traveloka, Trivago, Tokopedia, Booking.com, Tiket.com etc.

\section{Backward Integration Strategy}

There are two backward integration strategies. (1) Licensing less optimal number of employees at work functions; (2) Strengthen the company's financial position by finding sources of funding other than loans from banks, for example selling unproductive assets, issuance of bonds, right issue.

\section{Horizontal Integration Strategy}

There are three forward integration strategies. (1) Increase cooperation with vehicle suppliers (ATPM) such as Toyota, Honda, etc; (2) Increase cooperation / partners with other online taxi companies. PT XYZ must review the tariff system that has been implemented, because the tariff has followed the tariffs of online taxi companies which considered to be more profitable for online taxi companies; (3) Improve the driver wealth through reviewing the partnership system (both commission system and deposit system).

\section{Product Development Strategies}

There are four forward integration strategies. (1) Develop taxi products in the youth segment; (2) Differentiate taxi service for young customers with the concept of Segmentation, Targeting, Positioning (STP). The segmentation based on a age demographic data, the target market age is 21-30 years-old in Greater Jakarta. By this positioning, PT XYZ taxi could position itself as taxi for young people; (3) Open office channeling and increase taxi shelters in several strategic locations for offices, shopping, and entertainment places, such as in Indomaret, malls, and others; (4) Increase the diversity of taxi products for young customers. As a realization, companies can work on the young segment of young professionals.

\section{Market Penetration Strategy}

There are four market penetration strategies. (1) Increase the area of taxi operational networks, namely the Jabodetabek area for the young customers segment; (2) Increase the number of taxi drivers; (3) Promote intensively on taxi products to young consumers in the Greater Jakarta area; (4) Maintain lower floor tariffs with a focus on middle-income consumers.

\section{Market Development Strategy}

There are two market development strategies. (1) Focus on the domestic market. This means that the operational scope of taxis focuses on the national market; (2) Recruite employees in the fields of Technology and Information, Finance, and Marketing. 


\section{Strategic Action Plan}

Strategic action plan is an action plan that executed by the company in realizing the programs in a certain time based on the company's long-term recommendations. The long-term planning period in a strategic action plan has long term orientation for about 5-10 years (David 2011). In this study, the time span of the strategic action plan could be implemented by PT XYZ is for the next five years, from 2018 to 2023, as presented in Apendix 2. In Apendix 2, there are three main targets that must be improved by PT XYZ to win the competition in the taxi industry. The three objectives are: (1) Improve financial performance; (2) Increase driver productivity, improve taxi operating systems; (3) Improve service quality, and expand taxi market share. The first and second targets have implemented in the next 3 years from 2019-2021. The focus of the programs that has been implemented are the future integration strategy (during 2019), backward integration strategy (during 2019-2020), and horizontal strategy (during 20192022). The third target which focuses on improving service quality and market share, the strategic action plan takes place during 2019-2023 in the apendix 4. Meanwhile, the implemented programs in product development strategies are market penetration strategy and market development strategy.

\section{CONCLUSION}

Based on the analysis of the results of the evaluation of the internal environment, it was found that the highest factor in terms of strength of PT XYZ was a strong and strategic taxi distribution network in big cities. The weakness factor is the weak company's financial position. Meanwhile, based on the evaluation analysis of external environment, the highest factor is a high level of mobility and transportation needs. Furthermore, the threat factor is the standardization of fares, the number of fleets, and online taxi identity is minimum. The results of the analysis of the formulation of competing strategies with the IE matrix show that the company is in cell I (grow and build). Meanwhile, the results of decision making by the QSPM method obtained from the Total Attractiveness Score (TAS). The results of the priority strategy sequence are: (1) Forward integration strategy; (2) Backward integration strategy; (3) Horizontal integration strategy; (4) Product development strategy; (5) Market penetration strategy; 6) market development strategy. The limitations of this study cover the business unit level strategy (strategic business unit), namely the regular taxi business units of each competing corporation. The proposed improvement in the next research is to examine strategy at the corporate level that not only involve one business unit, but other business units such as the premium taxi segment and other supporting taxi business units.

\section{REFERENCES}

Asosiasi Penyelenggara Jasa Internet Indonesia. 2016. Statistik Pengguna Internet Indonesia. Jakarta: APJII. 
BISMA (Bisnis dan Manajemen)

Volume 12 Issue 1, October 2019

E-ISSN 2549-7790, P-ISSN 1979-7192

Page 66-87

Badan Pusat Statistik. (2016). Proyeksi Penduduk Menurut provinsi 2010-2035. Jakarta: Badan Pusat Statistik.

Chain, W. Y., Chank, L. N., Lau,. K. W., \& Lei., J. C. (2016). Taxi app market analysis in Hongkong. Journal of Economics Business And Management, 4(3), 239-243.

Chandler, A. (1962), Strategy and Structure, The MIT Press, Cambridge, MA.

Chaudhary, M. L., Joshi., C. Y. (2016). Strategy analysis of urban public transport industry: a case of Ahmedabad, Gujarat in India. Journal NMIMS Management in India, 19(9), 81-101.

Credit Suisse Estimates. (2015). Indonesia Transport Sector [ulasan]. Jakarta: Equity Research.

David, F. R. (2011). Strategic Management: Manajemen Strategi Konsep. Edisi 12. Jakarta: Salemba Empat.

Dess, G. G., \& Lumpkin, G. G. (2003). Strategic Management: Creating Competitive Adventages. New York, NY: McGraw-Hill.

Dinas Perhubungan dan Transportasi. (2013). Rencana Strategis Dinas Perhubungan Provinsi DKI Jakarta Tahun 2013-2017. Jakarta: Dinas Perhubungan Provinsi DKI Jakarta.

Enz, C.A. (2010), Hospitality Strategic Management, Concepts and Cases, 2nd ed., Wiley, Hoboken, NJ

Express Group. (2016). Annual report PT Express Transindo Utama Tbk Tahun 2016. http://www.expressgroup.co.id. Diakses tanggal 25 Januari 2018.

Fertel, C., Bahn, O., Vaillancourt, K. and Waaub, J.P. (2013), "Canadian energy and climate policies: a SWOT analysis in search of federal/provincial coherence", Energy Policy, Vol. 63, pp. 1139-1150.

Hasian, A. (2014). Formulasi strategi bersaing PT Express Transindo Utama Tbk (Express Group) dalam memenangkan persaingan bisnis taksi di Jakarta [tesis]. Yogyakarta: Universitas Gajah Mada.

He. F., \& Shen, Z. J. (2015). Modeling taxi services with smartphone based ehailing applications. Journal of Transport Policy, 58(3), 93-106.

He, L. and Liao, D. (2012), “Credit NGOs' sustainability in rural financial market: a SWOT analysis on DAYBANG”, Humanomics, Vol. 28 No. 3, pp. 200208.

Helms, M.M., Rodríguez, M.A., de los Ríos, L. and Hargrave, W. (2011), "Entrepreneurial potential in Argentina: a SWOT analysis", 
Competitiveness Review: An International Business Journal, Vol. 21 No. 3, pp. 269-287.

Indonesia Investment. 2017. Blue Bird Group. http://www.indonesiainvestments.com/id/bisnis/profil-perusahaan/blue-bird-group/item415?, diakses tanggal 9 Februari 2017.

Juniawan, E.J., \& Kusuma, A. A. G. A. A. (2017). Faktor-faktor yang Mempengaruhi customer switching dari taksi konvensional ke taksi online. E-Jurnal Manajemen Unud, 6(10), 5460-5488.

Kuncori, M. (2015). Strategi: Bagaimana Meraih Keunggulan Kompetitif: Jakarta: Penerbit Erlangga.

Mulyati, T., \& Utami, S. B. Penguatan usaha kecil menengah Melalui program tanggungjawab social perusahaan (Studi pada PT INKA Persero). Jurnal Capital, 2(2), 116-137.

Nag, R., Hambrick, D.C. and Chen, M-J. (2007), "What is strategic management, really? Inductive derivation of a consensus definition of the field", Strategic Management Journal, Vol. 28 No. 9, pp. 935-55.

Nurfanti, Y., Thayib, A., \& Zain, D. (2009). Faktor-faktor yang mempengaruhi kualitas layanan yang dipertimbangkan pelanggan (studi pada angkutan umum taksi di Malang). Jurnal Sosial dan Humaniora, 12(4), 740-757.

Ortega. Eva M.P., Azorin, Azorin. Jose F.M., and Cortes. E.C., 2010. Competitive strategy, structure and firm performance. Management Decision. Vol. 48. No. 8, 1282-1303

Pusat Bahasa Departemen Pendidikan Nasional. (2008). Kamus Besar Bahasa Indonesia. Jakarta: Pusat Bahasa Departemen Pendidikan Nasional.

Porter, M. E. (2008). Memahami strategi perusahaan. Jurnal Ekonomi dan Keuangan, 2(3), 130-147.

Porter, M. E. (2001). Strategi Bersaing: Teknik Menganalisis Industri dan Pesaing. Jakarta: Erlangga.

Riady, M. (1999). Mencari Peluang Sutengah Krisis. Jakarta: Universitas Pelita Harapan Press.

Selamat, S. M., Shafie, D. I. (2015). Sustainable competitive advantage of taximonger among taxi companies. International Academic Research Journal of Business And Technology, 1(2), 22-27.

Subagj, I. K. (2016). Pelaksanaan strategi bisnis dan pemasaran PT Blue Bird Tbk. Jurnal Manajemen Bisnis Krisnadwipayana, 4(3), 1-18. 
BISMA (Bisnis dan Manajemen)

Volume 12 Issue 1, October 2019

E-ISSN 2549-7790, P-ISSN 1979-7192

Page 66-87

Sugiyono. (2012). Metode Penelitian Kuantitatif Kualitatif dan R \& D. Bandung: Alfabeta.

Sullivan, Jack. (2015). An Uber Problem for the Cab Industry. Commonwealth Magazine, Available at http://commonwealthmagazine.org/economy/anuber-problem-for-the-cab-industry.

Syazwan Ab Talib, M. and Bakar Abdul Hamid, A. (2014), "Halal logistics in Malaysia: a SWOT analysis", Journal of Islamic Marketing, Vol. 5 No. 3, pp. 322-343.

Wang, X.P., Zhang, J. and Yang, T. (2014), "Hybrid SWOT approach for strategic planning and formulation in china worldwide express mail service", Journal of Applied Research and Technology, Vol. 12 No. 2, pp. 230-238.

Warpani, S. (1990). Merencanakan Sistem Perangkutan. Bandung: Institut Teknologi Bandung.

Wit, B. D., \& Mayer, R. (2003). Strategy: Process, Content, Context. $3^{\text {th }}$ Ed. London: Thompson Learning.

Zhang, Y. and Feng, L. (2013), "Development assessment of leisure agriculture in Henan province of China based on SWOT-AHP method", Journal of Industrial Engineering and Management, Vol. 6 No. 2, pp. 642-656.

Zhao, L., \& Xing, J. (2012). Taxi operation and management system based on distributed only taxi stations soving strategy. Applied Mechanics And Materials, 25(255), 1833-1836.

Zulkarnain, A., Whyuningtias, D., \& Putranto, T. S. (2018). Analysis of IFE, EFE, and QSPM matrix on business development strategy, Earth And Environmental Science, 126(62), 1-7.

Apendix 1. Financial Report PT XYZ Tahun 2015-2017 in Billion Rupiah

\begin{tabular}{ccccccccc}
\hline Component & $\mathbf{2 0 1 0}$ & $\mathbf{2 0 1 1}$ & $\mathbf{2 0 1 2}$ & $\mathbf{2 0 1 3}$ & $\mathbf{2 0 1 4}$ & $\mathbf{2 0 1 5}$ & $\mathbf{2 0 1 6}$ & $\mathbf{2 0 1 7}$ \\
\hline Revenue & 219,3 & 338,4 & 520,9 & 686,9 & 889,7 & 970,1 & 618,2 & 231,6 \\
Gross profit & 55,8 & 137,7 & 183,5 & 220,5 & 398,2 & 341,0 & 74,1 & $-123,7$ \\
Income before & 46,3 & 81,9 & 106,9 & 174,0 & 153,4 & 50,7 & $-223,4$ & $-102,4$ \\
tax & & & & & & & & \\
Net income & 35,0 & 59,6 & 79,2 & 132,4 & 118,9 & 32,2 & $-184,7$ & $-133,1$ \\
EBITDA & 158,5 & 232,1 & 327,2 & 408,7 & 522,1 & 514,4 & 246,2 & $-52,4$ \\
Earning per & 46,7 & 45,4 & 36,9 & 61,7 & 55,0 & 15,3 & $-85,9$ & $-36,1$ \\
share & & & & & & & & \\
Total asset & 658,5 & 999,2 & $1.782,8$ & $2.137,0$ & $3.011,3$ & $2.883,8$ & $2.557,2$ & $2.392,1$ \\
Total Liabilities & 516,5 & 792,0 & $1.096,0$ & $1.339,9$ & $2.118,8$ & $1.962,8$ & $1.820,5$ & $1.866,3$ \\
\hline Source: Result & & & &
\end{tabular}

Source: Result of the research (2019) 
Ahmad Saifi Athoillah, Muhammad Firdaus, \& Bunasor Sanim Competitive strategy of taxi company in facing environmental changes

Apendix 2. Asset of Taxi Vehicles of PT XYZ Year 2009-2017

\begin{tabular}{cccccccccc}
\hline Year & \multicolumn{8}{c}{ Taxi vehicles of PT XYZ Year 2009-2017 } & \multirow{2}{*}{} \\
& $\mathbf{2 0 0 9}$ & $\mathbf{2 0 1 0}$ & $\mathbf{2 0 1 1}$ & $\mathbf{2 0 1 2}$ & $\mathbf{2 0 1 3}$ & $\mathbf{2 0 1 4}$ & $\mathbf{2 0 1 5}$ & $\mathbf{2 0 1 6}$ & $\mathbf{2 0 1 7}$ \\
\hline $\begin{array}{c}\text { Regular taxi } \\
\text { PT XYZ }\end{array}$ & 3.198 & 4.922 & 6.002 & 8.035 & 10.550 & 11.050 & 11.050 & 11.050 & 9.700 \\
\hline
\end{tabular}

Source: Result of the research (2019)

Apendix 3. The Comparison of Regular Taxi Tariff of PT XYZ with Online Taxi

\begin{tabular}{cccccc}
\hline Component & $\begin{array}{c}\text { PT XYZ } \\
\text { (IDR) }\end{array}$ & $\begin{array}{c}\text { Blue Bird } \\
\text { (IDR) }\end{array}$ & $\begin{array}{c}\text { Uber car } \\
\text { (IDR) }\end{array}$ & $\begin{array}{c}\text { Grab car } \\
\text { (IDR) }\end{array}$ & $\begin{array}{c}\text { Go car } \\
\text { (IDR) }\end{array}$ \\
\hline Flag Fall & 6.500 & 6.500 & 3.000 & 2.500 & 3.500 \\
Triffs/km & 3.800 & 4.100 & 2.000 & 3.500 & 3.500 \\
Waiting time/mins & 700 & 700 & 300 & N/A & N/A \\
10 km ride, 30 mins & 47.500 & 47.500 & 32.000 & N/A & 40.000 \\
15 km ride, 45 mins & 67.500 & 67.500 & 46.500 & N/A & 60.000 \\
\hline
\end{tabular}

Source: Credite suisse estimate (2016) 
Apendix 4. Strategic Action Plan 2019-2023

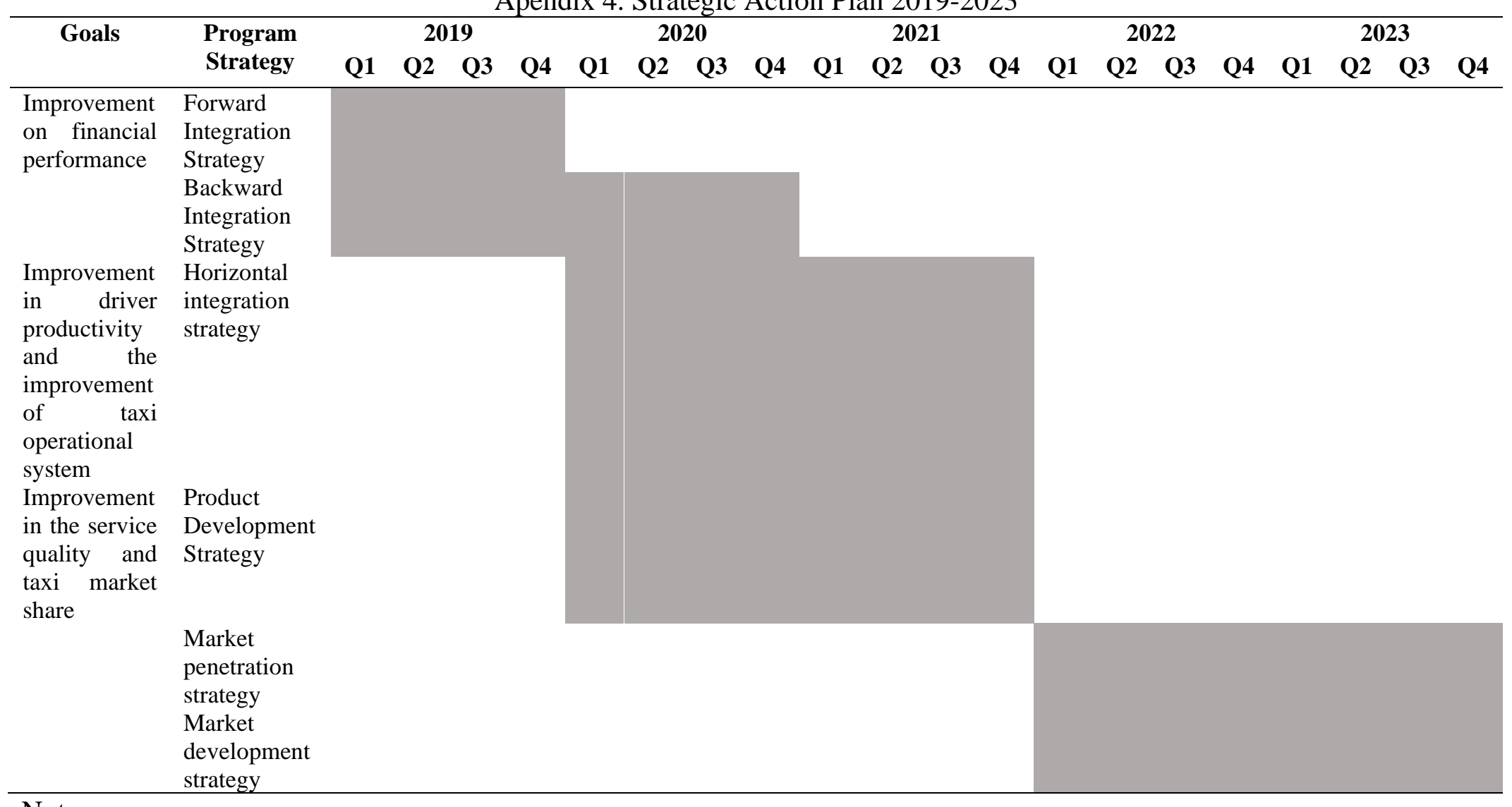

Notes:

Q : Quartal

: Achieved programs 